\title{
UJI EFEK ANTIMITOSIS EKSTRAK ETANOL DAUN WUNGU (Graptophyllum pictum (L.) Griff.) DENGAN METODE PENGHAMBATAN PEMBELAHAN SEL TELUR (Tripneustes gratilla L.) TERFERTILISASI
}

\section{Sitti Amirah}

\author{
Fakultas Farmasi Universitas Muslim Indonesia \\ Email : amirahsitti85@gmail.com.
}

\begin{abstract}
Antimitotic assay is one of the toxicity assay methods widely used in detection of cytotoxic activity of new compounds from natural materials. This research aimed to examine the effects of antimitotic and determine the $I C_{50}$ and $I C_{80}$ values of the ethanol extract of purple leaves with method of fertilized egg cell division inhibition Tripneustes gratilla $L$. The cell observation were visually carried out under a microscope by counting the number of cells that divided and did not divide after being incubated for \pm 2 hours. The results of this research showed that the $I C_{50}$ and $I C_{80}$ value of ethanol extract of purple leaves are $2,275 \times 10^{-2} \mu \mathrm{g} / \mathrm{ml}$ and $1,54 \times 10^{-2}$ $\mathrm{mg} / \mathrm{ml}$ respectively. Based on the values, the ethanol extract of purple leaves is active as an antimitotic, despite the potential values can be lower than vincristine which can inhibit $80 \%$ egg cell Tripneustes gratilla $L$. fertilized with $I C_{50}$ and $I C_{80}$ values of $1,462 \times 10^{-4} \mathrm{\mu g} / \mathrm{ml}$ and $4.69 \times 10^{-5} \mathrm{mg} / \mathrm{ml}$.
\end{abstract}

Keywords : Graptophyllum pictum L., Antimitotic, Tripneustes gratilla L.

\section{PENDAHULUAN}

Kanker termasuk salah satu penyakit degeneratif yang sulit disembuhkan bahkan tidak jarang menyebabkan kematian. Pola hidup yang tidak sehat dapat meningkatkan factor resiko terjadinya kanker, diantaranya merokok, kurang berolahraga, stress, makanan yang tinggi lemak dan rendah serat, serta kondisi lingkungan yang tidak sehat (Ahmad, 2008). Dalam keadaan normal, sel-sel tubuh makhluk hidup secara alami melakukan pembelahan. Pembelahan ini dikendalikan oleh gen, enzim dan hormon-hormon tubuh atas perintah otak. Pada kondisi tertentu, sel kanker yang timbul berasal dari mutasi atau perubahan gen sehingga sel tidak dapat berproliferasi secara normal, akibatnya sel akan mengalami peningkatan proliferasi yang akan menimbulkan perubahan jaringan. Keadaan proliferasi sel yang abnormal dinamakan kanker (Hariyanto,2009). Sel-sel kanker memiliki kemampuan 
Uji Efek Antimitosis Ekstrak Etanol Daun Wungu Dengan Metode Penghambatan Pembelahan Sel Telur Terfertilisasi

untuk menginvasi jaringan lainnya baik secara langsung dijaringan yang bersebelahan (invasi) maupun migrasi sel ketempat yang jauh (metastasis) (Krishna, 2000).

Menurut laporan Riskesdas (2007) prevalensi kanker mencapai 4,3 per 1000 penduduk dan menjadi penyebab kematian nomor tujuh $(5,7 \%)$ setelah stroke, tuberkulosis, hipertensi, trauma, perinatal dan diabetes melitus (Riskesdas, 2007). Berdasarkan laporan Riskesdas (2013) prevalensi kanker meningkat seiring dengan bertambahnya usia dimana lebih banyak menyerang perempuan daripada laki-laki, dan angka prevalensi di kota lebih tinggi daripada di desa (Riskesdas, 2013).

Pada umumnya, obat-obat antikanker yang ada saat ini memiliki banyak efek samping karena dapat mempengaruhi sel-sel normal. Idealnya suatu obat yang digunakan dalam terapi tidak membahayakan jaringan sehat. Hal inilah yang menjadi dasar pencarian obat antikanker dari bahan alam yang diharapkan memiliki efek samping sedikit dan harga yang relatif lebih murah. Berbagai penelitian telah dilakukan dalam pemanfaatan senyawa-senyawa bahan alam untuk terapi kanker. Salah satu tanaman yang diduga memiliki potensi sebagai antikanker adalah daun wungu (Graptophyllum pictum (L.) Griff.).

Pada tahun 2003, Isnawati dkk melaporkan bahwa daun ungu mengandung komponen kimia berupa tanin, antosianin, leukoantosianin dan flavonoid. Efek sitotoksik dari tumbuhan polifenol ditunjukkan melalui mediasi apoptosis. Polifenol utamanya flavonoid memiliki kemampuan untuk mengikat ion protein dan ion logam, sehingga memungkinkan flavonoid dapat memperoleh signal apoptosis melalui berbagai reseptoratau protein. Selainitu, flavonoid juga memiliki efek sebagai antioksidan yang dapat mencegah serangan radikal bebas pada DNA. Sejumlah polifenol juga dapat menghambat isomerase topo I/topo II (Vidyalakshmi, 2007).

\section{METODE PENELITIAN}

\section{Alat dan Bahan Penelitian}

Alat-alat yang digunakan pada penelitian ini adalah aerator, autoklaf, erlenmeyer, labu ukur, mikropipet, mikroskop, objek gelas dan dek gelas, seperangkat alat maserasi, seperangkat alat rotavapor, timbangan analitik, timbangan ohaus, tabung Eppendorf.

Bahan-bahan yang digunakan dalam penelitian ini adalah air laut bebas protozoa, air suling, ekstrak etanol daun wungu (Graptophyllum 
Uji Efek Antimitosis Ekstrak Etanol Daun Wungu Dengan Metode Penghambatan Pembelahan Sel Telur Terfertilisasi

pictum (L.) Griff.), pelarut etanol 70\%, $\mathrm{KCl} 10 \%$, kertas saring, vinkristin kalbe ${ }^{\circledR}$ injection $1 \mathrm{mg} / \mathrm{ml}$.

Prosedur Kerja

Pengambilan dan Pengolahan Sampel

Daun wungu (Graptophyllum pictum (L.) griff.) yang dikumpulkan pada pagi hari dan diambil dari Kota Ambon Propinsi Maluku. Daun wungu yang telah dikumpulkan kemudian dicuci bersih, dikeringkan ditempat yang terlindung dari sinar matahari langsung. Sampel yang telah kering selanjutnya dihaluskan kemudian dilakukan proses ekstraksi.

Pemilihan dan Pemiliharaan Hewan Uji

Hewan uji yang digunakan dalam penelitian ini adalah Tripneustes gratilla L. jantan dan betina. Dimana Tripneustes gratilla L. ini dipelihara dalam aquarium yang berisi air laut bersih yang dilengkapi dengan aerator dan diadaptasi selama 24 jam.

\section{Penyiapan dan Pembuatan Bahan}

\section{a. Pembuatan larutan $\mathrm{KCl} 10 \% \mathrm{~b} / \mathrm{v}$}

Sebanyak 10 gram $\mathrm{KCl}$ dimasukkan kedalam labu tentukur $100 \mathrm{ml}$ kemudian ditambahkan air suling sedikit demi sedikit, sambil dikocok dan dicukupkan volumenya sampai $100 \mathrm{ml}$. b. Penyiapan air laut bersih untuk media

Air laut bersih yang akan digunakan sebagai air media dan untuk membersihkan media uji dengan cara menyaring dan disterilkan di autoklafsehingga bebas dari protozoa.

c. Pembuatan sediaan uji

Sampel uji ekstrak etanol daun wungu (Graptophyllum pictum (L.) Griff.) dibuat dalam 3 konsentrasi yaitu $10 \mu \mathrm{g} / \mathrm{ml}, 100$ $\mu \mathrm{g} / \mathrm{ml}$ dan $1000 \mu \mathrm{g} / \mathrm{ml}$.Sampel ekstrak etanol daun wungu (Graptophyllum pictum (L.) Griff.) ditimbang sebanyak $10 \mathrm{mg}$ dalam tabung Eppendorf dan dilarutkan dengan $1 \mathrm{ml}$ etanol hingga diperoleh konsentrasi $10 \mathrm{mg} / \mathrm{ml}$ $(10000 \mu \mathrm{g} / \mathrm{ml})$ sebagai larutan stok. Larutan stok kemudian dipipet sebanyak $1 \mu \mathrm{l}, 10 \mu \mathrm{l}, 100 \mu \mathrm{l}$ ke dalam tabung Eppendorf yang masing-masing telah berisi $899 \mu \mathrm{l}$, $890 \mu \mathrm{l}$ dan $800 \mu \mathrm{l}$ air laut bebas protozoa, diuapkan etanol dengan menggunakan tangas air pada suhu $60-80^{\circ} \mathrm{C}$ selama 15 menit, setelah dingin ditambahkan $100 \mu \mathrm{l}$ cairan berisi zigot yang diperoleh setelah 20 menit terjadinya fertilisasi untuk mendapatkan 
Uji Efek Antimitosis Ekstrak Etanol Daun Wungu Dengan Metode Penghambatan Pembelahan Sel Telur Terfertilisasi

konsentrasi $10 \mu \mathrm{g} / \mathrm{ml}, 100 \mu \mathrm{g} / \mathrm{ml}$ dan $1000 \mu \mathrm{g} / \mathrm{ml}$.

\section{Pembuatan sediaan vinkristin}

Vinkristin sebagai pembanding dibuat dalam 3 konsentrasi yaitu $0,01 \mu \mathrm{g} / \mathrm{ml}$, $0,1 \mu \mathrm{g} / \mathrm{ml}$, dan $1 \mu \mathrm{g} / \mathrm{ml}$. Vinkristin 1 $\mathrm{mg} / \mathrm{ml}$ dipipet $100 \mu \mathrm{l}$ dilarutkan dalam air laut dan dicukupkan volumenya $1 \mathrm{ml}$ hingga diperoleh konsentrasi $100 \mu \mathrm{g} / \mathrm{ml}$ sebagai larutan stok. Di pipet $10 \mu$ larutan stok dan dicukupkan volumenya 1 $\mathrm{ml}$ hingga diperoleh konsentrasi 1 $\mu \mathrm{g} / \mathrm{ml}$. Dipipet $1 \mu \mathrm{l}$ larutan stok dan dicukupkan volumenya $1 \mathrm{ml}$ hingga diperoleh konsentrasi $0,1 \mu \mathrm{g} / \mathrm{ml}$. Dipipet $0,1 \mu \mathrm{l}$ larutan stok dan dicukupkan volumenya $1 \mathrm{ml}$ hingga diperoleh konsentrasi 0,01 $\mu \mathrm{g} / \mathrm{ml}$.

Penyiapan Sel Telur dan Sperma Tripneustes gratilla L.

Tripneustes gratilla L. jantan dan betina diinduksi dengan menyuntikkan $1 \mathrm{ml} \mathrm{KCl} 10 \%$ ke dalam bagian gonad. Sperma yang berwarna putih susu dan sel telur yang berwarna kuning keemasan ditampung pada gelas kimia yang berbeda dan berisi air laut bebas protozoa. Setelah itu dimasukkan pada lemari pendingin. Fertilisasi dilakukan dengan cara $1 \mathrm{ml}$ sperma dan $4 \mathrm{ml}$ sel telur difertilisasikan dalam gelas kimia yang berisi $50 \mathrm{ml}$ air laut bebas protozoa.

\section{Pengujian sampel}

Kontrol negatif yang digunakan yaitu air laut bebas protozoa sebanyak $900 \mu \mathrm{l}$ ditambahkan $100 \mu \mathrm{l}$ zigot dan kontrol pelarut yaitu etanol sebanyak $10 \mu$ ditambahkan $890 \mu$ air laut bebas protozoa, lalu diuapkan pelarutnya (etanol) lalu ditambahkan $100 \mu$ l cairan berisi zigot.

Pembanding menggunakan vinkristin dengan konsentrasi 0,01 $\mu \mathrm{g} / \mathrm{ml}, 0,1 \mu \mathrm{g} / \mathrm{ml}$, dan $1 \mu \mathrm{g} / \mathrm{ml}$. Untuk membuat konsentrasi $1 \mu \mathrm{g} / \mathrm{ml}$ maka dibuat terlebih dahulu larutan sampel dengan konsentrasi $10 \mu \mathrm{g} / \mathrm{ml}$, dengan cara dipipet sebanyak $1 \mu$ dari larutan stok ke dalam vial, lalu ditambahkan $899 \mu \mathrm{l}$ air laut bebas protozoa dibuat sebanyak 2 kali, salah satunya akan dijadikan larutan stok sampel untuk membuat konsentrasi $0,1 \mu \mathrm{g} / \mathrm{ml}$, untuk konsentrasi 0,1 $\mu \mathrm{g} / \mathrm{ml}$ masing-masing dipipet $1 \mu$ dari larutan stok $1 \mu \mathrm{g} / \mathrm{ml}$ dan ditambahkan $899 \mu$ air laut bebas protozoa dibuat sebanyak 2 kali, salah satunya akan dijadikan larutan stok sampel untuk membuat konsentrasi $0,01 \mu \mathrm{g} / \mathrm{ml}$, untuk membuat konsentrasi $0,01 \mu \mathrm{g} / \mathrm{ml}$ maka dipipet 1 $\mu \mathrm{l}$ dari larutan stok konsentrasi 0,1 $\mu \mathrm{g} / \mathrm{ml}$ lalu ditambahkan 899 air laut bebas protozoa, kemudian 
Uji Efek Antimitosis Ekstrak Etanol Daun Wungu Dengan Metode Penghambatan Pembelahan Sel Telur Terfertilisasi

dipindahkan ke dalam tabung Pengamatan sel yang eppendorf dan ditambahkan masingmembelah dilakukan setelah 2 jam masing $100 \mu \mathrm{l}$ cairan berisi zigot. inkubasi di bawah mikroskop dengan Dilakukan replikasi 3 kali untuk setiap sampel uji, kontrol dan pembanding. Selanjutnya disimpan pada suhu 15$20^{\circ} \mathrm{C}$ dengan diselingi pengocokan.

Pengamatan sel yang
membelah dilakukan setelah 2 jam
inkubasi di bawah mikroskop dengan
mengambil gambar setiap sampel.
Pengamatan dilakukan dengan
menghitung jumlah sel yang terhambat
dan total sel untuk dihitung sebagai
$\mathrm{IC}_{50}$ dan $\mathrm{IC}_{80}$.

HASIL PENELITIAN

Tabel 1. Hasil pengamatan penghambatan pembelahan sel telur Tripneustes gratilla L. pada ekstrak etanol daun wungu (Graptophyllum pictum (L.) Griff.).

\begin{tabular}{|c|c|c|c|c|c|c|}
\hline Sampel & $\begin{array}{c}\text { Konsentrasi } \\
(\mu \mathrm{g} / \mathrm{ml})\end{array}$ & Replikasi & $\begin{array}{c}\text { Sel yang } \\
\text { membelah }\end{array}$ & $\begin{array}{l}\text { Sel yang } \\
\text { dihambat }\end{array}$ & $\begin{array}{c}\text { Total } \\
\text { sel }\end{array}$ & $\begin{array}{c}\% \text { Penghambatan } \\
\text { sel }\end{array}$ \\
\hline \multirow{9}{*}{ 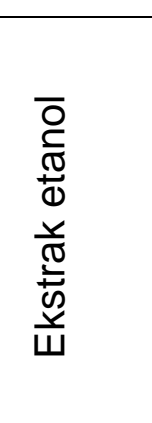 } & \multirow{3}{*}{ (myini) } & 1 & 5 & 33 & 38 & 86,84 \\
\hline & & 2 & 10 & 50 & 60 & 83.33 \\
\hline & & 3 & 4 & 29 & 33 & 87,88 \\
\hline & \multirow{3}{*}{100} & 1 & 8 & 50 & 58 & 86,21 \\
\hline & & 2 & 4 & 47 & 51 & 92,16 \\
\hline & & 3 & 6 & 33 & 39 & 84,62 \\
\hline & \multirow{3}{*}{1000} & 1 & 3 & 31 & 34 & 91,18 \\
\hline & & 2 & 3 & 30 & 33 & 90,91 \\
\hline & & 3 & 2 & 21 & 23 & 91,30 \\
\hline
\end{tabular}

Tabel 2. Hasil pengamatan penghambatan pembelahan sel telur Tripneustes gratilla L. pada vinkristin (kontrol positif).

\begin{tabular}{|c|c|c|c|c|c|c|}
\hline Sampel & $\begin{array}{c}\text { Konsentrasi } \\
(\mu \mathrm{g} / \mathrm{ml})\end{array}$ & Replikasi & $\begin{array}{l}\text { Sel yang } \\
\text { membelah }\end{array}$ & $\begin{array}{l}\text { Sel yang } \\
\text { dihambat }\end{array}$ & $\begin{array}{c}\text { Total } \\
\text { sel }\end{array}$ & $\begin{array}{c}\% \text { Penghambatan } \\
\text { sel }\end{array}$ \\
\hline \multirow{9}{*}{ 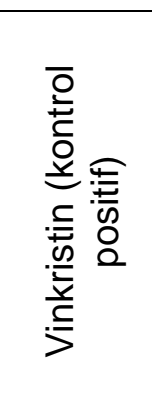 } & \multirow{3}{*}{0,01} & 1 & 13 & 41 & 54 & 75,93 \\
\hline & & 2 & 18 & 65 & 83 & 78.31 \\
\hline & & 3 & 10 & 54 & 64 & 84,38 \\
\hline & \multirow{3}{*}{0,1} & 1 & 7 & 62 & 69 & 89,86 \\
\hline & & 2 & 20 & 64 & 84 & 76,19 \\
\hline & & 3 & 6 & 38 & 44 & 86,36 \\
\hline & \multirow{3}{*}{1} & 1 & 4 & 59 & 63 & 93,65 \\
\hline & & 2 & 5 & 56 & 61 & 91,80 \\
\hline & & 3 & 1 & 78 & 79 & 98,73 \\
\hline
\end{tabular}


Uji Efek Antimitosis Ekstrak Etanol Daun Wungu Dengan Metode Penghambatan Pembelahan Sel Telur Terfertilisasi

Tabel 3. Hasil pengamatan penghambatan pembelahan sel telur Tripneustes gratilla L. pada air laut (kontrol negatif) dan pelarut etanol (kontrol pelarut).

\begin{tabular}{cccccc}
\hline Sampel & Rep. & $\begin{array}{c}\text { Sel yang } \\
\text { membelah }\end{array}$ & $\begin{array}{c}\text { Sel yang } \\
\text { dihambat }\end{array}$ & $\begin{array}{c}\text { Total } \\
\text { sel }\end{array}$ & \% Penghambatan sel \\
\hline Air laut & 1 & 140 & 5 & 145 & 3,45 \\
(kontrol negatif) & 2 & 181 & 7 & 188 & 3,72 \\
& 3 & 174 & 10 & 184 & 5,43 \\
\hline \multirow{2}{*}{ Air laut + etanol } & 1 & 173 & 14 & 187 & 7,49 \\
(Kontrol pelarut) & 2 & 168 & 16 & 184 & 8,70 \\
& 3 & 154 & 18 & 172 & 10,47 \\
\hline
\end{tabular}

\section{PEMBAHASAN}

Uji antimitosis merupakan salah satu metode uji toksisitas yang banyak digunakan dalam mendeteksi aktivitas sitotoksik senyawa baru dari bahan alam. Metode ini dapat dilakukan dengan cepat, murah, mudah dan dapat diulang (Gunarto \& Setabudi, 2002). Uji antimitosis juga memiliki kelebihan yaitu dapat memberikan gambaran potensi senyawa uji dalam menghambat pertumbuhan sel uji dengan parameter yang digunakan adalah $\mathrm{IC}_{50}$ dan $\mathrm{IC}_{80}$ (Ana, 2014).

Penelitian ini menggunakan ekstrak etanol daun wungu (Graptophyllum pictum (L.) Griff.). pengujian efek antimitosis menggunakan sel telur dan sel sperma Tripneustes gratilla Linn, berdasarkan pada proses fertilisasinya yaitu fertilisasi eksternal sehingga dapat digunakan untuk pengamatan. Sel sperma dan ovum yang telah difertilkan diinkubasi selama 2 jam karena pada rentan waktu tersebut terjadi pembelahan sel, dari satu sel induk membelah menjadi dua sel anak (Sloane, 2004). Uji penghambatan fertilisasi dilakukan di tempat gelap dengan tujuan untuk menyerupai pada kondisi di dalam laut. Pengamatan kemudian dilakukan dengan melihat dan menghitung jumlah sel yang membelah dan jumlah sel yang mengalami penghambatan pembelahan sel.

Pengambilan sel telur dan sel sperma Tripneustes gratilla L., dilkakukan dengan cara menginduksikan $\mathrm{KCl} 10 \%$ pada bagian gonadnya. KCL $10 \%$ merupakan larutan yang bersifat hipotonis yang dapat mengakibatkan berkurangnya perbedaan polaritas pada membran sel antara intra dan ekstra sel atau disebut dengan terjadinya depolarisasi dan mengakibatkan terjadinya perbedaan potensial. Hal inilah yang menyebabkan sel sperma dan ovum 
Uji Efek Antimitosis Ekstrak Etanol Daun Wungu Dengan Metode Penghambatan Pembelahan Sel Telur Terfertilisasi

menjadi terdesak keluar dari gonad (Ikawati, 2008).

Penentuan efek antimitosis dari ekstrak etanol daun wungu ditentukan berdasarkan efek sitotoksik dengan melihat persentase sel telur Tripneustes gratilla L. yang mengalami penghambatan pembelahan. Vinkristin digunakan sebagai pembanding karena berasal dari tanaman periwinkle, Vinca rosea. Vinkristin bekerja menghambat mitosis pada fase metafase (Fase $M$ ). Obat ini terikat pada protein mikrotubular, tubulin yang sifatnya bergantung pada GTP (Guanosin Triphospat) dan menghambat kemampuan tubulin untuk berpolimerisasi membentuk mikrotubulus. Akibatnya, terbentuk agregat-agregat parakristalin yang terdiri dari diner tubulin dan obat alkaloid. Apparatus gelendong disfungsional yang dihasilkan terhenti pada metafase, sehingga menghambat pemisahan kromosom dan proliferase sel (Harvey \& Champe, 2013).

Hasil penelitian dari ekstrak etanol daun wungu (Graptophyllum pictum (L.) Griff.) dapat dilihat pada tabel 7 , dengan daya penghambatan rata-rata paling besar adalah pada konsentrasi $1000 \mu \mathrm{g} / \mathrm{ml}$ yaitu $82,25 \%$. Vinkristin sebagai pembanding, memilki daya penghambatan rata-rata paling besar adalah pada konsentrasi $1 \mu \mathrm{g} / \mathrm{ml}$ yaitu 90,53\% (terlihat pada tabel 8). Kontrol pelarut (air laut dan etanol) memiliki penghambatan ratarata 13,08\%. Data tersebut memperlihatkan bahwa efek antimitosis akan meningkat pada konsentrasi yang lebih tinggi, hal ini disebabkan karena semakin besar konsentrasi yang digunakan maka semakin besar pula kandungan senyawa kimia yang dapat menghambat pembelahan zigot Tripneustes gratilla L.

Pengujian ini didasarkan pada penentuan nilai $\mathrm{IC}_{50}$ dan $\mathrm{IC}_{80}$. Nilai $\mathrm{IC}_{50}$ menunjukkan nilai konsentrasi yang menghasilkan penghambatan proliferasi sel sebesar $50 \%$ dan nilai $\mathrm{IC}_{80}$ menunjukkan nilai konsentrasi yang menghasilkan penghambatan proliferasi sel sebesar $80 \%$, nilai $\mathrm{IC}_{50}$ dan $\quad \mathrm{IC}_{80}$ menunjukkan potensi ketoksikan suatu senyawa terhadap sel (Meiyanto dkk , 2003).

Hasil analisis probit menunjukkan bahwa pemberian ekstrak etanol daun wungu (Graptophyllum pictum (L.) Griff.) memiliki $I C_{50}$ rata-rata sebesar 2,275 $x \quad 10^{-2} \mu \mathrm{g} / \mathrm{ml}$, sedangkan nilai $\mathrm{IC}_{80}$ adalah $1,54 \times 10^{-2} \mathrm{mg} / \mathrm{ml}$. Nilai $I_{50}$ vinkristin sebesar $1,462 \times 10^{-4} \mathrm{\mu g} / \mathrm{ml}$, dan nilai $I C_{80}$ adalah $4,69 \times 10^{-5} \mathrm{mg} / \mathrm{ml}$. 
Uji Efek Antimitosis Ekstrak Etanol Daun Wungu Dengan Metode Penghambatan Pembelahan Sel Telur Terfertilisasi

Hasil tersebut menunjukkan bahwa ekstrak etanol daun wungu (Graptophyllum pictum (L.) Griff.) aktif sebagai antimitosis. Meskipun, vinkristin memiliki potensi penghambatan pembelahan sel yang jauh lebih besar dibandingkan ekstrak etanol daun wungu (Graptophyllum pictum (L.) Griff.). Suatu bahan dinyatakan aktif jika penghambatan sel terjadi $\left(\mathrm{IC}_{80-100}\right)$ dicapai pada konsentrasi lebih rendah dari pada 16 $\mathrm{mg} / \mathrm{ml}$ (Rahman dkk, 2001).

Ekstrak etanol daun wungu (Graptophyllum pictum (L.) Griff.) memiliki kemampuan penghambatan terhadap sel telur Tripneustes gartilla L. Hal ini diduga daun ungu memiliki kandungan senyawa aktif seperti tanin, antosianin, leukoantosianin dan flavonoid. Berdasarkan literatur, tanaman yang mengandung flavonoid memiliki efek sitotoksik dari tumbuhan polifenol dapat menunjukkan mediasi apoptosis. Polifenol utamanya flavonoid memiliki kemampuan untuk mengikat ion protein dan ion logam, sehingga memungkinkan flavonoid dapat memperoleh signal apoptosis melalui berbagai reseptor atau protein. Selainitu, flavonoid juga memiliki efek sebagai antioksidan yang dapat mencegah serangan radikal bebas pada DNA. Sejumlah polifenol juga dapat menghambat isomerase topo I/topo II (Vidyalakshmi, 2007).

\section{KESIMPULAN}

Berdasarkan hasil penelitian dan pembahasan dapat disimpulkan bahwa ekstrak etanol daun wungu (Graptophyllum pictum (L.) Griff.) aktif sebagai antimitosis sel telur Tripneustes gratilla $L$. terfertilisasi dengan nilai $\mathrm{IC}_{50}$ dan $\mathrm{IC}_{80}$ adalah sebesar $2,275 \times 10^{-2} \mu \mathrm{g} / \mathrm{ml}$ dan $1,54 \times 10^{-}$ $2 \mathrm{mg} / \mathrm{ml}$ meskipun potensinya lebih rendah dibanding vinkristin yang dapat menghambat $80 \%$ sel telur Tripneustes gratilla $\mathrm{L}$. terfertilisasi dengan nilai $\mathrm{IC}_{50}$ dan $\mathrm{IC}_{80}$ adalah1,462 $\times 10^{-4} \mu \mathrm{g} / \mathrm{ml}$ dan $4,69 \times 10^{-5} \mathrm{mg} / \mathrm{ml}$.

\section{DAFTAR PUSTAKA}

Ahmad, A. 2008. Pola Penyebab Kematian di Indonesia Berubah. Seminar Dietary Fibre, is Benefit or Myth. Jakarta. Diakses pada tanggal 20 November 2014. http://www.glorianet.org/arsip/b3570.

Ana, I., dan Ismiyati, I. 2014. Cytotoxic Activity of Ethanolic Extract of Persea americana mill. Leaves on Hela Cervical Cancer Cell. Traditional Medicine Journal, 19(1) 24-28. Diakses pada tanggal 23 maret 2015. http://mot.farmasi.ugm.ac.id/file s/45.\%20Ana.pdf

Gunarto, dan Setabudi, E. 2002. Perkembangan Gonad Bulu Babi (Tripneustes gratilla) di Kepulauan Spermonde, Sulawesi Selatan. Badan Riset 
Uji Efek Antimitosis Ekstrak Etanol Daun Wungu Dengan Metode Penghambatan Pembelahan Sel Telur Terfertilisasi
Kelautan dan Perikanan.
Departemen Kelautan dan
Perikanan. jakarta

Hariyanto, N. 2009. Mengenal, Mencegah, Dan dan Mengatasi Silent Killer Kanker. Pustaka Widyarama. Jawa Tengah.

Harvey, R.A., dan Champe, P.C. 2013. Farmakologi Ulasan Bergambar Ed. 4. Penerbit Buku Kedokteran EGC. Jakarta.

Ikawati, Z. 2008. Pengantar Farmakologi Molekuler. Penerbit Gadjah Mada University Press. Yogyakarta.

Isnawati, A., dan Iwang S. 2003. Pemeriksaan Senyawasenyawa Turunan Fenol Daun Hendeuleum (Graptophyllum pictum (L.) Griff.). Media Litbang Kesehatan Volume XIII Nomor 1 Tahun 2003. Diakses Pada Tanggal 12 Oktober 2014. http://bahan-

alam.fa.itb.ac.id/detail.php?id=2 $\underline{51}$

Krishna, G., and Makoto H. 2000. In vivo rodent micronucleus assay: protocol, conduct and data interpretation. Journal of Elsevier Science, Vol. 455, Pages 155-166.

Meiyanto, E., Sismindari., Candra., dan Moerdiani. 2003. Efek Antiproliferatif Ekstrak Etanol Daun dan Kulit Batang Tanaman Cangkring (Erithryma fusca L) Terhadap Sel Hela. Majalah Farmasi Indonesia. Diakses pada tanggal 17 maret 2015. http://ccrc.farmasi.ugm.ac.id/wp -content/uploads/cv-p-edyoktober-2007.doc

Rahman, A.U., Choudary, M., dan Thompson, W. 2001. Biossay Tehnique For Drug Development. Academic Publisher. Australia.

Riskesdas. 2007. Laporan Hasil Riset Kesehatan Dasar Indonesia. Jakarta:Depkes RI. Diakses pada tanggal 28 September 2014.

http://dinkes.jatimprov.go.id/use rimage/laporan\%20hari\%20kan ker\%2013.pdf

Riskesdas. 2013. Laporan Hasil Riset Kesehatan Dasar Indonesia. Jakarta:Depkes RI. Diakses pada tanggal 28 September 2014.

http://depkes.go.id/downloads/ri skesdas2013/Hasil\%20Riskesd as\%202013.pdf

Sloane, Ethel. 2004. Anatomi dan Fisiologi Untuk Pemula. Penerbit Buku Kedokteran EGC. Jakarta.

Vidyalakshmi, A. I., Dorni C., Hannah R.V. 2007. Anti-mitotic and cytotoxic Effect of Mussaenda queensirkit. Journal of Pharmacology and Toxicology 2 (7): 660-665, 2007. Diakses pada tanggal 23 Oktober 2014. http://connection.ebscohost.com /c/articles/29414728/anti-mitoticcytotoxic-effect-mussaendaqueensirkit 